\title{
Hubungan Riwayat Pola Pemberian ASI dengan Tingkat Kecerdasan Anak SD di SDN 01 Sawahan Kecamatan Padang Timur Kota Padang
}

\author{
Syntia Ambelina, Chundrayetti, Nur Indrawati Lipoeto
}

\begin{abstract}
Abstrak
Pola pemberian ASI dinyatakan para ahli berhubungan dengan tingkat kecerdasan anak. Akan tetapi, persentase pemberian ASI di Indonesia sampai saat ini masih tergolong rendah. Data Depkes RI tahun 2006 dan 2007 menunjukkan bahwa anak di Indonesia yang mendapat asupan ASI eksklusif dan ASI hingga usia 2 tahun tidak mencapai $50 \%$. Penelitian ini bertujuan untuk menentukan apakah terdapat hubungan antara riwayat pola pemberian ASI dengan tingkat kecerdasan anak SD. Desain penelitian ini adalah penelitian dengan jenis cross sectional study. Populasi penelitian adalah semua siswa kelas III - V di SD Negeri 01 Sawahan. Sampel diambil sebanyak 104 orang dengan metode proportional stratified random sampling. Data dikumpulkan dengan kuesioner untuk mengetahui riwayat pola pemberian ASI yang diterima responden saat bayi. Data diolah dengan uji statistik chi square menggunakan program SPSS 16.0. Hasil analisis univariat menunjukkan anak dengan tingkat kecerdasan tinggi $(68,3 \%)$ dan anak dengan tingkat kecerdasan sedang $(31,7 \%)$. Terdapat $16,3 \%$ anak yang memiliki riwayat pola pemberian ASI baik dan $83,7 \%$ anak memiliki riwayat pola pemberian ASI kurang. Hasil analisis bivariat menunjukkan tidak terdapat hubungan bermakna antara riwayat pola pemberian ASI dengan tingkat kecerdasan anak $(p=0,173)$. Penelitian ini memperlihatkan bahwa tidak terdapat hubungan antara riwayat pola pemberian ASI dengan tingkat kecerdasan anak SD di SDN 01 Sawahan Kecamatan Padang Timur Kota Padang.
\end{abstract}

Kata kunci: Pola pemberian ASI, Tingkat kecerdasan

\begin{abstract}
Breastfeeding patterns declared by the experts are associated with the level of children intelligence. However, the percentage of breastfeeding in Indonesia is still relatively low. Department of Health Republic of Indonesia data for 2006 and 2007 showed that children in Indonesia who received exclusive breastfeeding intake and breastfeeding until 2 years old didn't reach 50\%. The aim of this study is to know whether there is a relationship between breastfeeding patterns history with the level of intelligence of elementary school student. The design of this study was a cross sectional study. The study population was all elementary school students in the 3rd until 5th grade in SDN 01 Sawahan. Samples were taken as many as 104 people with a proportional stratified random sampling method. Data were collected with a questionnaire to determine the history of the breastfeeding pattern of the respondents when they were baby. Data processed by the chi-square statistical test using SPSS 16.0. The results of univariate analysis showed children with high intelligence level (68.3\%) and children with moderate intelligence level (31.7\%). There are $16.3 \%$ of children had a both breastfeeding pattern history and $83.7 \%$ of children had a lack breastfeeding patterns history. Results of the bivariate analysis showed no significant relationship between breastfeeding patterns history with the level of children intelligence $(p=0.173)$. This study shows that there is no relationship between breastfeeding patterns history with the level of children intelligence of elementary school students in SDN 01 Sawahan, Eastern District of Padang.
\end{abstract}

Keywords:breastfeeding patterns, level of intelligence

Affiliasi penulis : Fakultas Kedokteran Universitas Andalas,

Korespondensi: Syntia Ambelina, email:

osyn_ambelina@yahoo.com, Telp: 085374729403

\section{PENDAHULUAN}

Kecerdasan merupakan suatu kemampuan dalam menyelesaikan masalah dan kemampuan untuk belajar beradaptasi atau menyesuaikan diri dengan pengalaman sehari-hari. ${ }^{1}$ Salah satu aspek kecerdasan yang paling berperan adalah kemampuan spasial, suatu konsep abstrak, yang meliputi persepsi dan pemahaman. Pemahaman sangat penting bagi anak usia sekolah. $^{2}$

Matematika merupakan pelajaran yang membutuhkan kemampuan analisis dan pemahaman yang baik $^{3}$. Beberapa penelitian membuktikan bahwa dengan kecerdasan tinggi seseorang juga memilik kemampuan pemahaman dan analisis yang baik sehingga mempengaruhi kinerja yang berhubungan dengan tugas akademik terutama pelajaran matematika. ${ }^{2}$ Nunes menemukan bahwa kemampuan spasial berhubungan dengan kemampuan penalaran dan penting dalam mempelajari pelajaran matematika serta berpengaruh dalam pencapaian prestasi matematika anak sekolah. ${ }^{4}$ Siswa dengan kemampuan analisis yang baik akan memiliki nilai akademik matematika lebih tinggi dari pada siswa dengan kemampuan analisis rendah. ${ }^{5}$

Salah satu faktor yang mempengaruhi kecerdasan adalah pemenuhan nutrisi saat bayi terutama ASI. ${ }^{6}$ ASI terdiri dari berbagai makro dan mikronutrien yang sangat dibutuhkan bayi. Lemak merupakan salah satu makronutrien utama dalam ASI yang terdiri dari AA dan DHA dan merupakan penyusun $60 \%$ komposisi otak manusia. AA dan DHA penting dalam optimalisasi perkembangan otak 
terutama dalam proses sinaptogenesis dan mielinisasi sel-sel saraf yang bermanfaat untuk kecerdasan bayi. ${ }^{6}$ Nelson menjelaskan bahwa semakin banyak sinaps antar sel saraf maka kemampuan menerima, mengolah, menyimpan, dan merespon rangsangan akan semakin kompleks. ${ }^{7}$

Berdasarkan Profil Kesehatan Indonesia Tahun 2004 yang dilakukan oleh Depkes RI didapatkan bahwa $48,47 \%$ dari 2.812 .775 bayi di Indonesia mendapat asupan ASI eksklusif, 41,36\% dari anak Indonesia berusia 2-4 tahun mendapat ASI hingga usia 2 tahun dan meningkat menjadi $42,80 \%$ pada tahun 2005. Untuk Provinsi Sumatera Barat $36,56 \%$ dari anak berusia $2-4$ tahun mendapat ASI hingga usia 2 tahun dan meningkat menjadi $41,39 \%$ pada tahun 2005 . $^{8,9}$

Pola pemberian ASI dinyatakan para ahli memiliki hubungan dengan kemampuan kognitif anak. Berdasarkan penelitian yang dilakukan Oddy di Australia Barat diketahui bahwa anak berusia 10 tahun yang mendapat ASI eksklusif pada masa bayi memiliki nilai akademik yang lebih tinggi terutama dalam kemampuan matematika, membaca, dan mengeja daripada anak yang tidak mendapat ASI eksklusif. ${ }^{10}$ Selain itu, Bora menemukan bahwa pemberian ASI selama 4 minggu berkorelasi positif dengan peningkatan kognitif yang progresif. Penelitian pada anak-anak berusia 11 tahun di Jerman yang mendapat asupan ASI selama 4 minggu memiliki kemampuan matematika 9,18 poin lebih tinggi dari pada anak-anak yang tidak pernah mendapat ASI. ${ }^{11}$ Crory juga menemukan bahwa dari 8.226 orang anak berusia 9 tahun di Irlandia yang mendapat asupan ASI eksklusif saat bayi memiliki kemampuan matematika 7,42 poin lebih tinggi jika dibandingkan dengan anak-anak yang tidak mendapat asupan ASI. ${ }^{12}$

Padang merupakan salah satu kota dengan standar pendidikan terbaik di Sumatera Barat yang menempati peringkat 4 untuk nilai UN tahun 2011. Kota Padang terdiri dari 409 SD yang tersebar di 11 kecamatan. Berdasarkan data Dinas Pendidikan Kota Padang tentang Peringkat Hasil Ujian Nasional SD seKota Padang didapatkan bahwa SDN 01 Sawahan merupakan salah satu SD dengan peringkat UN tertinggi di kota Padang dan memiliki rata-rata hasil UN yang paling stabil dalam 2 tahun terakhir. ${ }^{13,14}$

Dari berbagai penelitian di atas dapat disimpulkan bahwa ASI dapat meningkatkan kecerdasan serta meningkatkan perkembangan kognitif anak.Selain itu, pemberian ASI juga berperan penting dalam mempengaruhi kemampuan pemahaman dan analisis anak sehingga dapat meningkatkan nilai akademik terutama pelajaran matematika.Tujuan penelitian ini adalah untuk mengetahui hubungan antara riwayat pola pemberian ASI dengan tingkat kecerdasan anak SD.

\section{METODE}

Desain penelitian adalah penelitian dengan jenis cross sectional study.Populasi penelitian dalah semua siswa kelas III-V di SDN 01 Sawahan, Kecamatan Padang Timur, Kota Padang. Sampel berjumlah 104 orang yang diambil berdasarkan metode proportional stratified random sampling pada 3 tingkatan kelas. Kriteria inklusi adalah siswa SDN 01
Sawahan kelas III-V dan bersedia berpartisipasi dalam penelitian dengan nenandatangani informed concent. Kriteria eksklusi antara lain anak yang lahir premature, lahir kembar, BBLR, memiliki riwayat kejang saat balita, dan pernah dirawat di rumah sakit.

Variabel independen penelitian adalah pola pemberian ASI yang merupakan cara pemberian ASI yang sesuai dengan takarannya dimana bayi diberi ASI secara eksklusif sejak lahir hingga usia 4 bulan, dilanjutkan hingga usia 2 tahun, dan pemberian makanan tambahan yang sesuai mulai diberikan saat bayi berusia sekitar 4 bulan. Data didapatkan melalui wawancara dengan alat ukur kuesioner. Hasil ukur pola pemberian ASI baik bila $100 \%$ jawaban benar dan pola pemberian ASI kurang bila $<100 \%$ jawaban benar, Variabel dependen penelitian adalah tingkat kecerdasan yang merupakan tingkat kemampuan memperoleh, menggali, serta menggunakan pengetahuan dalam memahami dan menghubungkan objek dengan gagasan serta menggunakan pengetahuan dengan cara yang lebih efektif. Cara ukur yang digunakan dengan menilai rata-rata nilai rapor matematika siswa dalam 2 semester terakhir, yaitu nilai rapor matematika semester II tahun ajaran 2011/2012 dan nilai rapor matematika semester I tahun ajaran 2012/2013. Hasil ukur tingkat kecerdasan tinggi apabila memiliki rata-rata nilai rapor matematika dari 81-100 dan tingkat kecerdasan sedang apabila memiliki rata-rata nilai rapor matematika dari $65-80 .^{15}$

Langkah-langkah pengolahan data yang dilakukan yaitu memeriksa kelengkapan data dari kuesioner, memberikan kode pada setiap data variabel yang telah terkumpul, memasukkan data ke dalam komputer dengan program Statistical Program for Social Science (SPSS) 16.0, dan memeriksa kembali data yang telah dimasukkan untuk memastikan bahwa data tersebut telah bersih dari kesalahan. Analisis data terdiri dari analisis univariat dan bivariat. Analisis bivariat digunakan untuk menganalisis hubungan yang signifikan antara dua variabel yaitu variabel pola pemberian ASI dengan tingkat kecerdaan anak SD menggunakan uji Chi Square dengan derajat kemaknaan $p \leq 0,05$.

\section{HASIL}

\section{Data dan Karakteristik Sampel}

Penelitian dilaksanakan di SDN 01 Sawahan Kecamatan Padang Timur dengan jumlah sampel sebanyak 104 orang yang berasal dari 207 orang populasi. Data total siswa dan siswi didapatkan dari daftar absensi di setiap kelas. Jumlah sampel untuk setiap tingkatan kelas secara berurutan berjumlah 33 orang $(31,7 \%), 32$ orang $(30,7 \%)$, dan 39 orang $(37,6 \%)$. Total sampel perempuan berjumlah 56 orang $(53,9 \%)$ dan sampel laki-laki berjumlah 48 orang $(46,1 \%)$. Sampel terbanyak berasal dari kelas V.

\section{Riwayat Pola Pemberian ASI}

Polapemberian ASI dinilai berdasarkan riwayat pemberian $\mathrm{ASI}$, riwayat pemberian $\mathrm{ASI}$ eksklusif, riwayat usia penghentian ASI, dan riwayat usia mendapatkan susu formula. Pola pemberian ASI diklasifikasikan menjadi pola baik dan pola kurang.Pola pemberian ASI dinyatakan baik apabila $100 \%$ riwayat pola pemberian ASI yang diberikan 
sesuai kriteria dan dinyatakan kurang apabila riwayat pola pemberian ASI yang sesuai kriteria $<100 \%$.

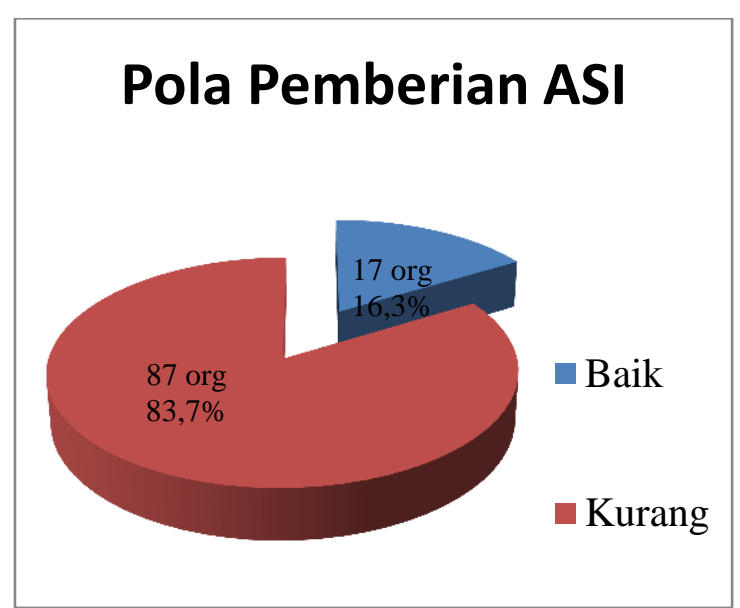

Gambar 1. Riwayat Pola Pemberian ASI pada Anak SD

Gambar diatas menunjukkan bahwa sebagian besar sampel mendapatkan pola pemberian ASI kurang $(83,7 \%)$. Klasifikasi riwayat pola pemberian ASI diatas dinilai berdasarkan hasil analisis data dibawah ini:

a. Riwayat Pemberian ASI

Tabel 1. Riwayat Pemberian ASI pada Anak SD

\begin{tabular}{cccc}
\hline No. & Pemberian ASI & Jumlah & $\%$ \\
\hline 1. & ASI & 102 & 98,08 \\
2. & Tidak ASI & 2 & 1,92 \\
\hline & TOTAL & 104 & 100
\end{tabular}

Dari tabel 1.terlihat bahwa hampir seluruh sampe memiliki riwayat mendapat ASI (98,08\%).

b. Riwayat Pemberian ASI Eksklusif

Tabel 2. Riwayat Pemberian ASI Eksklusif pada Anak

\begin{tabular}{cccc}
\hline No. & $\begin{array}{c}\text { Pemberian ASI } \\
\text { Eksklusif }\end{array}$ & Jumlah & $\%$ \\
\hline 1. & ASI eksklusif & 70 & 67,31 \\
2. & ASI tidak eksklusif & 32 & 30,77 \\
3. & Tidak ASI & 2 & 1,92 \\
\hline & TOTAL & 104 & 100 \\
\hline
\end{tabular}

Dari tabel 2.dapat dilihat bahwa sebagian besar sampel memiliki riwayat mendapat ASI eksklusif hingga usia 4 bulan $(67,31 \%)$.

c. Riwayat Usia Penghentian ASI

Tabel 3. Riwayat Usia Penghentian ASI pada Anak SD

\begin{tabular}{cccc}
\hline No. & Usia Henti ASI & Jumlah & $\%$ \\
\hline 1. & $<2$ tahun & 59 & 56,73 \\
2. & $\geq 2$ tahun & 43 & 41,35 \\
\hline & TOTAL & 102 & 98,08 \\
\hline
\end{tabular}

Tabel 3.menunjukkan bahwa sebagian besar sampel berhenti ASI sebelum mencapai usia 2 tahun $(56,73 \%)$. d. Riwayat Usia Mendapatkan Susu Formula

Tabel 4. Riwayat Usia Mendapatkan Susu Formula pada Anak SD

\begin{tabular}{cccc}
\hline No. & Susu Formula & Jumlah & $\%$ \\
\hline 1. & $<4$ bulan & 39 & 37,5 \\
2. & $\geq 4$ bulan & 65 & 62,5 \\
\hline & TOTAL & 104 & 100 \\
\hline
\end{tabular}

Dari tabel 4.terlihat bahwa sebagian besar sampel baru mendapat susu formula setelah melewati usia 4 bulan $(63,51 \%)$.

\section{Tingkat Kecerdasan}

Tingkat Kecerdasan diklasifikasikan menjadi tingkat kecerdasan tinggi dan tingkat kecerdasan sedang. Sampel dinyatakan memiliki tingkat kecerdasan tinggi apabila memiliki rata-rata nilai rapor matematika dengan rentang 81-100 dan dinyatakan memiliki tingkat kecerdasan sedang apabila memiliki rata-rata nilai rapor matematika dengan rentang 6580.Pengelompokan tingkat kecerdasan sampel dapat dilihat pada tabel 5.berikut:

Tabel 5. Tingkat Kecerdasan Anak SD

\begin{tabular}{cccc}
\hline No. & Tingkat Kecerdasan & Jumlah & $\%$ \\
\hline 1. & Tinggi & 71 & 68,3 \\
2. & Sedang & 33 & 31,7 \\
\hline & TOTAL & 104 & 100 \\
\hline
\end{tabular}

Tabel 5.menunjukkan bahwa sebagian besar sampel memiliki tingkat kecerdasan tinggi $(68,3 \%)$.

\section{Analisis Bivariat}

Tabel 6. Hubungan Riwayat Pola Pemberian ASI dengan Tingkat Kecerdasan Anak SD

\begin{tabular}{|c|c|c|c|c|c|c|c|}
\hline \multirow{3}{*}{$\begin{array}{c}\text { Pola } \\
\text { Pemberian } \\
\text { ASI }\end{array}$} & \multicolumn{6}{|c|}{ Tingkat Kecerdasan } & \multirow{3}{*}{$\begin{array}{c}P \\
\text { valu } \\
e\end{array}$} \\
\hline & \multicolumn{2}{|c|}{ Tinggi } & \multicolumn{2}{|c|}{ Sedang } & \multicolumn{2}{|c|}{ Total } & \\
\hline & $f$ & $\%$ & $f$ & $\%$ & $\mathrm{~F}$ & $\%$ & \\
\hline Baik & 14 & 13,46 & 3 & 2,89 & 17 & 16,35 & \\
\hline Kurang & 57 & 54,81 & 30 & 28,84 & 87 & 83,65 & 0,173 \\
\hline TOTAL & 71 & 68,27 & 33 & 31,73 & 104 & 100 & \\
\hline
\end{tabular}

Berdasarkan Tabel 6 dapat dilihat bahwa tingkat kecerdasan tinggi lebih banyak dimiliki oleh sampel dengan pola pemberian ASI kurang $(54,81 \%)$ daripada sampel dengan pola pemberian ASI baik $(13,46)$. Hasil uji statistik menunjukkan tidak terdapat hubungan yang bermakna antara pola pemberian ASI dengan tingkat kecerdasan $(p>0,05)$.

\section{PEMBAHASAN}

\section{Riwayat Pola Pemberian ASI}

Dari hasil penelitian yang dilakukan terhadap 104 orang sampel, didapatkan 102 orang (98\%) memiliki riwayat mendapatkan ASI, 70 orang (67,31\%) mendapatkan asupan ASI eksklusif, 43 orang $(41,35 \%)$ mendapat ASI hingga usia 2 tahun, dan 65 orang $(62,5 \%)$ mendapat asupan susu formula setelah usia 4 bulan.

Data pemberian ASI eksklusif yang didapatkan lebih rendah daripada hasil penelitian yang 
diperoleh Depkes RI dan Yulia. Depkes RI mendapatkan bahwa $78,59 \%$ bayi di Sumatera Barat mendapatkan asupan ASI eksklusif. ${ }^{8}$ Selain itu, penelitian Yulia di Jakarta Selatan juga didapatkan bahwa $73,30 \%$ dari total sampel penelitiannya mendapatkan ASI eksklusif. ${ }^{16}$ Akan tetapi, data pemberian ASI hingga usia 2 tahun yang didapatkan hampir serupa dengan data Depkes RI di Sumatera Barat yaitu 41,39\%.

Yulia menjelaskan bahwa cakupan pemberian ASI eksklusif yang tinggi berhubungan dengan akses pelayanan kesehatan yang tersedia. Semakin banyak jumlah tempat pelayanan dan petugas kesehatan yang tersedia, maka akan semakin mudah dalam menjangkau dan memberi penyuluhan kepada seluruh lapisan masyarakat. ${ }^{16}$

Dengan menghubungkan seluruh komponen riwayat pola pemberian ASI yang diterima sampel saat bayi dapat disimpulkan bahwa sampel yang mendapat pola pemberian ASI baik berjumlah 17 orang (16,3\%) dan jauh lebih sedikit daripada sampel yang mendapat pola pemberian ASI kurang yang berjumlah 87 orang $(83,7 \%)$

Apabila dianalisa lebih lanjut, dapat dilihat bahwa walaupun persentase pemberian ASI eksklusif di lokasi penelitian sudah cukup tinggi (67,31\%) namun jika dinilai secara keseluruhan persentase pola pemberian ASI baik masih rendah (16,3\%). Ibu yang memberikan ASI eksklusif belum tentu memberi ASI hingga usia 2 tahun kepada anaknya karena prioritas program pemerintah selama ini masih lebih menitikberatkan kepada pemberian ASI eksklusif.

\section{Tingkat Kecerdasan}

Salah satu aspek yang mempengaruhi kecerdasan adalah kemampuan spasial yang berhubungan dengan kemampuan penalaran dan penting dalam pencapaian prestasi matematika., Sehingga dapat disimpulkan bahwa prestasi matematika dapat dijadikan sebagai salah satu tolak ukur dalam menilai tingkat kecerdasan.

Dari penelitian yang dilakukan, didapatkan rata-rata nilai rapor matematika yang diperoleh sampel berkisar dari nilai 77 sampai 94,5 dimana nilai terbanyak yang diperoleh sampel adalah nilai 77 sebanyak 19 orang (18,3\%). Sedangkan dari uji statistik didapatkan rata-rata nilai distribusi 83,27 (SD $\pm 5,08$ ).

Depdiknas mengelompokkan kemampuan rata-rata siswa menjadi kemampuan tinggi (81-100), sedang (65-80), dan rendah (50-64) ${ }^{15}$. Apabila hasil penelitian yang dilakukan disesuaikan dengan kriteria yang dikeluarkan oleh Depdiknas didapatkan 71 orang $(68,3 \%)$ sampel memiliki tingkat kecerdasan tinggi karena memiliki rentang nilai $81-100$ dan 33 orang $(31,7 \%)$ sampel memiliki tingkat kecerdasan sedang karena memiliki rentang nilai 65-80.

Menurut Fahmie, tingkat kecerdasan merupakan faktor internal yang mempengaruhi prestasi seorang anak. Selain faktor interna, faktor eksternal seperti lingkungan belajar dan fasilitas belajar yang tersedia ikut mempengaruhi prestasi yang diperoleh. ${ }^{17}$ Faktor eksternal lain yang ikut mempengaruhi prestasi seorang anak adalah asal sekolah tempat mereka belajar. Semakin baik kualitas dan sarana prasarana yang dimiliki sekolah, persaingan antar siswa akan semakin tinggi, dan semakin tinggi pula motivasi siswa dalam belajar sehingga nilai yang didapatkan siswa di sekolah akan semakin baik. ${ }^{18}$

Pernyataan Fahmie dan Khaerudin mendukung hasil penelitian yang mendapatkan bahwa sampel yang menuntut ilmu di salah satu SD terbaik di Kota Padang memiliki tingkat kecerdasan tinggi yang lebih banyak 2 kali lipat daripada sampel dengan kecerdasan sedang.

\section{Hubungan Riwayat Pola Pemberian ASI dengan Tingkat Kecerdasan}

Meskipun hasil penelitian menunjukkan bahwa anak yang mendapat pola pemberian ASI baik lebih sedikit daripada anak yang mendapat pola pemberian ASI kurang, namun perbandingan tingkat kecerdasan tinggi dan sedang pada anak yang mendapat pola pemberian ASI baik lebih besar daripada anak yang mendapat pola pemberian ASI kurang. Akan tetapi, hasil analisis secara statistik menunjukkan bahwa tidak terdapat hubungan yang bermakna antara riwayat pola pemberian ASI dengan tingkat kecerdasan anak SD di SDN 01 Sawahan.

Hasil serupa juga ditemukan dalam penelitian yang dilakukan oleh Rothstein di AS, dimana pada awalnya peneliti mendapatkan bahwa pemberian ASI eksklusif ikut mempengaruhi peningkatan skor kecerdasan.Akan tetapi, setelah disesuaikan dengan pekerjaan, tingkat kecerdasan (IQ), dan keahlian orangtua, pemberian ASI tidak lagi mempengaruhi skor kecerdasan. Sehingga Rothstein menyimpulkan bahwa tidak terdapat hubungan yang signifikan antara pemberian ASI dengan tingkat kecerdasan anak. ${ }^{19}$

Berbeda dengan penelitian yang dilakukan oleh Wigati terhadap anak berusia 6-9 tahun di SDN Cepoko 01 Semarang yang mendapatkan terdapat hubungan bermakna antara pemberian ASI eksklusif dan usia penghentian ASI dengan tingkat kecerdasan anak SD setelah disesuaikan dengan nilai $I^{20}$. Penelitian yang dilakukan oleh Novita di lingkungan Puskesmas Cigondewah Bandung juga menunjukkan bahwa bayi yang mendapatkan ASI eksklusif selama 6 bulan memiliki IQ lebih tinggi 13,9 poin daripada bayi yang tidak mendapat ASI eksklusif. Selain itu, sosioekonomi keluarga juga ikut mempengaruhi pola pemberian ASI.Orangtua dengan penghasilan keluarga tinggi lebih cenderung memberikan ASI eksklusif kepada bayinya. Diduga pengetahuan tentang ASI pada keluarga dengan pengahasilan tinggi lebih baik daripada keluarga dengan penghasilan rendah.

Menurut Der, orangtua dengan kecerdasan (IQ) yang tinggi cenderung memiliki keahlian, pekerjaan, serta sosio-ekonomi yang lebih baik. Selain itu, mereka juga memiliki wawasan pengetahuan yang lebih tinggi karena memiliki akses untuk mendapatkan informasi yang lebih lengkap dan akurat. Sehingga dengan pengetahuan tersebut, selain dapat memberikan ASI secara eksklusif orangtua juga lebih cenderung memberikan stimulasi dan pendidikan yang lebih baik kepada anak sejak dini. ${ }^{21}$

Sehingga dapat disimpulkan faktor genetik (IQ orangtua), pengetahuan orangtua, pola asuh, lingkungan rumah dan sekolah, fasilitas belajar, dan sosio-ekonomi keluarga menyebabkan pola pemberian ASI tidak mempengaruhi tingkat kecerdasan anak secara bermakna. 


\section{KESIMPULAN}

Berdasarkan penelitian yang telah dilakukan terhadap anak SD di SDN 01 Sawahan Kecamatan Padang Timur Tahun 2013 mengenai pola pemberian ASI dengan tingkat kecerdasan dapat disimpulkan bahwa:

1. Sebagian besar anak SD mendapatkan pola pemberian ASI kurang (83,7\%).

2. Lebih dari setengah anak SD memiliki tingkat kecerdasan tinggi $(68,3 \%)$.

3. Tidak terdapat hubungan yang bermakna antara pola pemberian ASI dengan tingkat kecerdasan anak SD di SDN 01 Sawahan Kecamatan Padang Timur.

\section{DAFTAR PUSTAKA}

1. Santrock JW. Child development. Edisi ke-11. Rachmawati M, Kuswanti, penterjemah. Jakarta: Erlangga; 2007.

2. Tambunan SM. Hubungan antara kemampuan spasial dengan prestasi belajar matematika. Makara Sosial Humaniora. 2006;10(1): 27-32

3. Diezmann CM, James JW. Identifying and supporting spatial intelligent in young children. contemporary issues in early childhood. 2000; 1(3): 299-313.

4. Nunes T, Peter B, Kathy S, Rossana B. Development of maths capabilities and confidence in primary school. Research Report DCSFRR118. 2009.

5. Yilmaz HB. On the development and measurement of spatial ability. International Electronic Journal of Elementary Education. 2009; 1(Issue 2).

6. Pusponegoro HD, Handryastuti $S$. Air susu ibu dan kecerdasan anak. Dalam: Badriul H, Rulina S, Aryono H, I Gusti AP, editor. Bedah ASI. Jakarta: IDAI; 2008. hlm. 111-23.

7. Novita L, Dida A, Gurnida, Herri G. Perbandingan fungsi kognitif bayi usia 6 bulan yang menddapat dan yang tidak mendapat asi eksklusif. Sari Pediatri. 2008; 9(6).

8. Depkes RI. Profil kesehatan indonesia 2004 (diunduh 5 Maret 2013). Tersedia dari: URL: HYPERLINK www.depes.go.id

9. Depkes RI. Profil kesehatan indonesia 2005 (diunduh 5 Maret 2013). Tersedia dari: URL:
HYPERLINK www.depes.go.id

10. Oddy $\mathrm{WH}$, et al. Breastfeeding duration and academic achievement at 10 years. Pediatrics. 2011; 127(1): e137-e45.

11. Bora C, Lacovou M, Sevilla M. The effect of breastfeeding on children's cognitive and noncognitive development. IZA. June 2012.

12. Crory MC. The effect of breastfeeding on children's educational test scores at nine years of age: results of an Irish cohort study. Social Science \& Medicine 2011; 72 (Issue 9): 1515-21.

13. Dinas Pendidikan Kota Padang. Peringkat hasil ujian nasional SD sekota Padang tahun 2009/2010.

14. Peringkat hasil ujian nasional SD se kota Padang tahun 2010/2011.

15. Depdiknas. Penetapan KKM SD. 2009 (diunduh 20 Juni 2013). Tersedia dari: URL: HYPERLINK http://www.scribd.com/doc/104856539/Penetapan -KKM-SD\#download.

16. Yulia RN. Hubungan tingkat pengetahuan, sikap dan karakteristik ibu dengan pola pemberian asi eksklusi di wilayah kerja puskesmas Pasar Minggu kecamatan Pasar Minggu Jakara Selatan (skripsi). Padang: Fakultas Kedokteran Universitas Andalas; 2006.

17. Fahmie A. Prestasi belajar yang rendah ditinjau dari intelegensi dan atribusi: studi kasus siswa SD. Fenomena. 2003; 1(2).

18. Khaerudin. Faktor-faktor yang mempengaruhi hasil UN (diunduh 13 September 2013). Tersedia dari: URL: HYPERLINK http://www.ilmupendidikan.net/2009/06/18/faktorfaktor-yang-mempengaruhi-hasil-un.php

19. Rothstein DS. Breastfeeding and children's early cognitive outcomes. Review of Economics and Statistics. Mei 2012.

20. Wigati PA. Hubungan antara riwayat lama pemberian ASI dan tingkat kecerdasan (IQ) siswa usia 6-9 tahun di SDN Cepoko 01 Semarang (skripsi). Semarang: Fakultas Kesehatan Masyarakat Universitas Diponegoro; 2005.

21. Der G, David B, lan JD. Effect of breast feeding on intelligence in children: prospective study, sibling pairs analysis, and meta-analysis. BMJ. 4 October 2006 